\title{
Aroeira (Schinus terebinthifolius Raddi) Fruit: Chemical Composition and Antioxidant Capacity
}

\author{
Silva, T. L.; de Oliveira, V. S.; Augusta, I. M.; Keller, L. M.; Gamallo, O. D.; \\ Saldanha, T.*
}

Rev. Virtual Quim., 2019, 11 (5), 1614-1624. Data de publicação na Web: 30 de outubro de 2019

http://rvq.sbq.org.br

\section{Fruto da Aroeira (Schinus terebinthifolius Raddi): Composição Química e Capacidade Antioxidante}

Resumo: A inserção de fontes naturais de compostos bioativos na dieta humana é essencial para a prevenção de diversas doenças degenerativas e crônicas. Desta forma, este estudo caracterizou a composição química e determinou a capacidade antioxidante do fruto da aroeira (Schinus terebinthifolius Raddi). Os ácidos graxos mais representativos foram os ácidos oleico $(34,51 \pm 0,50 \mathrm{~g} / 100$ g), palmítico $(24,53 \pm 0,38 \mathrm{~g} / 100 \mathrm{~g})$ e linoleico $(17,58 \pm 0,09 \mathrm{~g} / 100 \mathrm{~g})$. Fitosteróis como o $\beta$-sitosterol, estigmasterol e campesterol foram identificados, apresentando maiores conteúdos de $\beta$-sitosterol $(166,70 \pm 8,44 \mathrm{mg} / 100 \mathrm{~g})$. O teor de fenólicos totais foi $13,06 \pm 0,76 \mathrm{mg}$ AGE/g dry sample. Além disso, 0 extrato da aroeira apresentou potencial antioxidante para os ensaios de DPPH, FRAP e ABTS. Assim, estes resultados destacam os frutos de Schinus terebinthifolius Raddi como fonte promovedora de saúde, apresentando componentes funcionais e propriedades antioxidantes.

Palavras-chave: Schinus terebinthifolius Raddi; ácidos graxos; fitosteróis; capacidade antioxidante.

\begin{abstract}
The insertion of natural sources of bioactive compounds in the human diet is crucial for the prevention of several degenerative and chronic diseases. Thus, this study characterized the chemical composition and determined the antioxidant capacity of aroeira (Schinus terebinthifolius Raddi) fruit. The most representative fatty acids found were oleic (34.51 $\pm 0.50 \mathrm{~g} / 100 \mathrm{~g})$, palmitic $(24.53 \pm 0.38 \mathrm{~g} / 100 \mathrm{~g})$ and linoleic acid (17.58 $\pm 0 . \mathrm{g} / 100 \mathrm{~g})$. Phytosterols such as $\beta$-sitosterol, stigmasterol, and campesterol were identified, presenting greater contents of $\beta$-sitosterol $(166.70 \pm 8.44 \mathrm{mg} / 100 \mathrm{~g})$. The total phenolics level was $13.06 \pm 0.76 \mathrm{mg} \mathrm{GAE} / \mathrm{g}$. In addition, aroeira extract showed antioxidant potential in DPPH, FRAP, and ABTS assays. Thus, these results suggest Schinus terebinthifolius Raddi fruit as a health-promoting source that presents functional components and antioxidant properties.
\end{abstract}

Keywords: Schinus terebinthifolius Raddi; fatty acids; phytosterols; antioxidant capacity.

\footnotetext{
* University Federal Rural of Rio de Janeiro, Department of Food Technology, Institute of Technology, Rodovia Br 465 km 47, CEP 23890-000, Seropédica-RJ, Brazil.

$M$ tatysal@gmail.com

DOI: $10.21577 / 1984-6835.20190113$
} 


\section{Aroeira (Schinus terebinthifolius Raddi) Fruit: Chemical Composition and Antioxidant Capacity}

\section{Tatiana Labre da Silva, Vanessa Sales de Oliveira, Ivanilda Maria Augusta, Laura Monteiro Keller, Ormindo Domingues Gamallo, Tatiana Saldanha*}

University Federal Rural of Rio de Janeiro, Department of Food Technology, Institute of Technology, Rodovia Br 465 km 47, CEP 23890-000, Seropédica-RJ, Brazil.

*tatysal@gmail.com

Recebido em 30 de setembro de 2019. Aceito para publicação em 30 de setembro de 2019

1. Introduction

2. Material and Methods

\subsection{Chemicals}

2.2. Samples

2.3. Proximate composition

2.4. Fatty acids composition

2.5. Phytosterols

2.6. Preparation of aroeira fruit extract

2.7. Determination of total phenolics

2.8. DPPH free radical scavenging assay

2.9. ABTS assay

2.10. FRAP assay

2.11. Statistical analysis

\section{Results and Discussion}

\subsection{Proximate composition}

3.2. Fatty acids composition

3.3. Phytosterols

3.4. Determination of total phenolic contents and antioxidant properties

\section{Conclusion}

\section{Introduction}

Recently consumers' demand for natural and nutritive food has increased since they are more concerned about their healthy lifestyle habits. Bioactive compounds found in plants play an important role in human health, being associated to the prevention of several diseases. ${ }^{1,2}$ Thus, health-promoting components, which are widely available in the native Brazilian flora, must be studied and exploited. ${ }^{3}$ 
Aroeira (Schinus terebinthifolius Raddi) is a member of the Anacardiaceae family and native to South America, being extensively found in Brazil, where it is popularly known as "aroeira", "pimenta rosa", "aroeira pimenteira", "pimenta brasileira" or "aroeira da praia". Aroeira tree presents a great potential for exploration and use; while its fruits are commonly used as spice in culinary dishes, leaves and bark are traditionally applied by the folk medicine. ${ }^{4,5}$

Antioxidant, antimicrobial, antiinflammatory, antihypertensive, and anticancer potentials are attributed to aroeira, and its rich composition in bioactive compounds justifies its nutritional and pharmacological properties. ${ }^{6}$ Although the phytochemical composition depends on various factors, the presence of secondary metabolites, especially phenolic compounds, flavonoids and terpenoids have been described in the literature, highlighting aroeira antioxidant capacity. ${ }^{4,-9}$ These antioxidant components may provide protection against harmful free radicals and have been associated with lower incidence and mortality rates of cancer, heart and other degenerative diseases. ${ }^{10-12}$

In addition, the consumption of fatty acids and phytosterols naturally occurring in food of vegetal origin has also been demonstrating benefits to human health. Phytosterols may influence cholesterol absorption and reduce its level in blood serum, exhibiting a hypocholesterolemic function. ${ }^{13}$ Fatty acids regulate a variety of physiological and biological functions, such lipids may present a cholesterol-lowering effect and have a structural role in the brain, improving the cognitive development, for example. ${ }^{14,15}$

In this context, it is important to characterize the composition and antioxidant capacity of aroeira fruit. Thus, this study aimed to perform a detailed characterization of Schinus terebinthifolius Raddi fruit by means of proximate composition and functional lipids content. The total phenolics and antioxidant capacity were also determined.

\section{Material and Methods}

\subsection{Chemicals}

Gallic acid, (( \pm )-6-hydroxy-2,5,7,8tetramethychroman-2-carboxylic acid) (Trolox), 2,4,6-tris-2,4,6-tripyridyl-2-triazine (TPTZ) and 2,2-Diphenyl-1-picrylhydrazyl (DPPH) were obtained from Alfa Aesar (Ward Hill, MA, USA). 2,2'-azinobis (3-ethyl-benzothiazolione-6-sulphonate) (ABTS) was purchased from Fluka Chemie (Buchs, Switzerland). Tri-Sill reagent was acquired from Pierce (Rockford, IL, U.S.A.). The standard mixtures of fatty acids were obtained from Supelco TM 37 (FAME Mix 18919, Bellefonte, Pa., U.S.A.). Phytosterol standards, including Brassicasterol, Campesterol, Stigmasterol and $\beta$-Sitosterol, and undecanoic methyl ester were acquired from Sigma-Aldrich (St. Louis, MO, USA), as well as Sodium methoxide. HPLC grade nhexane was purchased from Mscience (Darmstadt, Germany), and all other analytical grade solvents were obtained from Vetec (Sigma, São Paulo, Brazil). The purities of the standards ranged from $95 \%$ to $99 \%$.

\subsection{Samples}

Aroeira fruits (Schinus terebinthifolius Raddi) were obtained from a local farm located in Seropédica, Rio de Janeiro, Brazil

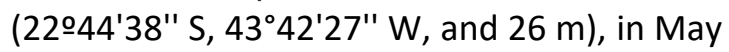
2013. The identification of plant material was authenticated by the staff of the Department of Botany, Institute of Biology, and a voucher specimen was deposited in the Herbarium of the UFRRJ under the number RBR 15557.

The fruits were manually collected at the ripe stage, free from any physical and microbial damage. Then, they were dried in a ventilated oven (Solab, SP, Brazil) at $30{ }^{\circ} \mathrm{C}$ for 24 hours and ground in a domestic processor (Walita, Brazil). Subsequently, the samples were stored in polyethylene bags at room temperature in the dark until analyses. 


\subsection{Proximate composition}

The protein content was accessed by the macro-Kjeldahl method, using the conversion factor of 6.25. The total fat level was determined by extracting a known weight of powdered sample with petroleum ether, using a Soxhlet apparatus. The ash content was obtained by incinerating the samples in a muffle furnace at $600{ }^{\circ} \mathrm{C}$. Total carbohydrate was calculated "by difference", using the formula: $100-(\%$ moisture $+\%$ lipids $+\%$ protein $+\%$ ash). Total energy was estimated by the following formula: Energy (Kcal) $=4 \mathrm{x}$ (g protein $+\mathrm{g}$ carbohydrate) $+9 \times$ (g lipid). ${ }^{16}$ The total fiber content was determined according to the procedures described by Adolfo Lutz Institute. ${ }^{17}$

\subsection{Fatty acids composition}

The samples ( $25 \mathrm{mg}$ ) were converted into methyl esters by transesterification. ${ }^{18}$ The fatty acids were determined using a gas chromatograph (Shimadzu GC 2010, Tokyo, Japan), equipped with a split injector (1:50), flame ionization detector and a workstation. The chromatographic separation was achieved in a fused silica CP-SIL 88 capillary column $(50 \mathrm{~m} \times 0.25 \mathrm{~mm}$ i.d., $0.20 \mu \mathrm{m}$ film thickness) (Chrompack, Middelburg, The Netherlands). The chromatographic conditions were: initial temperature $100^{\circ} \mathrm{C}(5$ minute) followed by $5{ }^{\circ} \mathrm{C} /$ minute up to $160^{\circ} \mathrm{C}$ (zero minute), $8{ }^{\circ} \mathrm{C} /$ minute up to $230{ }^{\circ} \mathrm{C}(12$ minute). The injector and detector temperatures were $250^{\circ} \mathrm{C}$ and $280{ }^{\circ} \mathrm{C}$, respectively. The equipment used hydrogen as the carrier gas at a flow rate of 1 $\mathrm{mL} /$ minute. In order to identify the chromatographic peaks of the sample, the retention times of FAME standards were used, and the quantification was performed by internal standardization, with undecanoic methyl ester as the internal standard.

\subsection{Phytosterols}

Phytosterols were obtained from direct saponification of samples ( $1 \mathrm{~g}$ of sample, 4 $\mathrm{mL}$ of a $50 \%$ ethanol solution of $\mathrm{KOH}$ and 6 $\mathrm{mL}$ of ethanol) at $20^{\circ} \mathrm{C}$ for $22 \mathrm{~h}$ in the dark and the nonsaponifiable matter was extract 4 times with hexane. ${ }^{19}$ The samples and standards were derivatized to thrimethylsilyl (TMS) ethers. ${ }^{20}$ The TMS derivates were diluted with $1 \mathrm{~mL}$ of hexane, filtered through a $22 \mu \mathrm{m}$ filter (Millipore, Maryland, MD, USA), and injected into a gas chromatograph (Shimadzu GC 2010, Tokyo, Japan), equipped with a split injector (1:20), a flame ionization detector, and a workstation. The TMS-ether derivates of sterols were separated in a capillary column Rtx-5-MS $(30 \mathrm{~m} \times 0.25 \mathrm{~mm} \times$ $0.25 \mu \mathrm{m}$, Restek, Bellefonte, USA). The oven program was: initial temperature, $230{ }^{\circ} \mathrm{C}(0$ min); a heating rate of $2{ }^{\circ} \mathrm{C} / \mathrm{min}$ to a temperature of $264{ }^{\circ} \mathrm{C}(5 \mathrm{~min}) ;$ and then a heating rate of $1{ }^{\circ} \mathrm{C} / \mathrm{min}$ to a final temperature of $275^{\circ} \mathrm{C}(2 \mathrm{~min})$. The injector temperature was $290^{\circ} \mathrm{C}$ and detector $350^{\circ} \mathrm{C}$. The carrier gas was hydrogen at a flow rate of $1 \mathrm{~mL} / \mathrm{min}$. Identification was done by comparison with the retention times of phytosterols standards. Quantification was done by external standardization with concentrations ranging from 0.05 to 1.0 $\mathrm{mg} / \mathrm{mL}$.

\subsection{Preparation of aroeira fruit extract}

The extract of Schinus terebinthifolius Raddi fruits was prepared at a concentration of $10 \mathrm{mg} / \mathrm{mL}$ in acetone: ethanol: water solution (40:30:30). The samples were submitted to agitation for one hour in the dark. $^{21}$

\subsection{Determination of total phenolics}

The total phenolic contents were obtained with the Folin-Ciocalteu reagent. ${ }^{22}$ Aliquots of 
$7 \mathrm{~mL}$ of deionized water were mixed with 0.5 $\mathrm{mL}$ of the extract and $0.5 \mathrm{~mL}$ of FolinCiocalteu reagent. After three minutes, $2 \mathrm{~mL}$ of $20 \%$ sodium carbonate solution was added to the mixture. Then, the mixture was heated in a water bath at $100{ }^{\circ} \mathrm{C}$ for one minute. The absorbance was measured at $685 \mathrm{~nm}$ using a spectrophotometer (Model NOVA 2000 UV). A calibration curve of standard gallic acid (from 5 to $50 \mu \mathrm{g} / \mathrm{mL}$, $r>0.99)$ was prepared and the results were expressed as $\mathrm{mg}$ gallic acid equivalent (GAE) per g of sample (dry basis).

\subsection{DPPH free radical scavenging assay}

Antioxidant capacity was determined by scavenging the radical 2,2-diphenyl-1picryhydrazyl (DPPH) as described by Rufino et al. ${ }^{23} \mathrm{~A}$ methanol solution containing 0.06 $\mathrm{mM}$ DPPH was prepared. Then, $0.1 \mathrm{~mL}$ of extract was added to $3.9 \mathrm{~mL}$ of DPPH solution. The mixture was homogenized and after $60 \mathrm{~min}$ the absorbance was measured at $517 \mathrm{~nm}$ using a spectrophotometer (Model NOVA 2000 UV). The quantification was performed by external standardization with a calibration curve of Trolox ranging from 100 to $2000 \mu \mathrm{M} / \mathrm{mL}$ ( $r>0.98$ ). Antioxidant capacity was expressed as the percentage of DPPH radical-scavenging activity (\% DPPH), which was calculated as follows: \%DPPH $=\left(A_{0}-A\right) /$ $\left.A_{0}\right) \times 100$, where $A_{0}$ is the absorbance of DPPH (control) and $A$ is the absorbance of each sample added with DPPH.

\subsection{ABTS assay}

Aliquots of $30 \mu \mathrm{L}$ of extracts were added to $3 \mathrm{~mL}$ of radical cation ABTS+ solution, formed by the chemical reaction with potassium persulfate. The absorbance was determined at $734 \mathrm{~nm}$ after $6 \mathrm{~min}$ at $30{ }^{\circ} \mathrm{C}$ using a spectrophotometer (Model NOVA 2000 UV). ${ }^{23}$ The free radical scavenging ability was expressed as $\mu \mathrm{mol}$ of Trolox Equivalent (TE) /g of sample. The quantification was performed by external standardization with a calibration curve of Trolox ranging from 100 to $2000 \mu \mathrm{M} / \mathrm{mL}$.

\subsection{FRAP assay}

Frap reagent was prepared by diluting an aqueous solution of $20 \mathrm{mM}$ TPTZ (2,4,6tripyridyl-s-triazine) and $20 \mathrm{mM}$ ferric chloride and $0.3 \mathrm{M}$ sodium acetate buffer $(\mathrm{pH}$ 3.6) at a ratio of $1: 1: 10(\mathrm{v}: \mathrm{v}: \mathrm{v})$. The reaction was started by adding $90 \mu \mathrm{L}$ of the extract to $270 \mu \mathrm{L}$ of distilled water and $2.7 \mathrm{~mL}$ of the FRAP reagent. The mixture was heated at $30{ }^{\circ} \mathrm{C}$ for $30 \mathrm{~min}^{23}$ The absorbance was measured at $595 \mathrm{~nm}$ using a spectrophotometer (Model NOVA 2000 UV). The free radical scavenging ability was expressed as $\mu \mathrm{mol}$ of $\mathrm{Fe}^{+2} / \mathrm{g}$ of the sample. The quantification was performed by external standardization using a calibration curve with concentrations ranging from 300 to 2000 $\mu \mathrm{M} / \mathrm{mL}(r>0.99)$.

\subsection{Statistical analysis}

The analyses were done in triplicate and the results were expressed as the mean \pm standard deviation.

\section{Results and Discussion}

\subsection{Proximate composition}

The proximate composition of aroeira is presented in Table 1 . The moisture level determined was $13.54 \pm 0.02 \mathrm{~g} / 100 \mathrm{~g}$ of sample (fresh weight). Previous studies found values ranging from 12.09 to $29.04 \% .{ }^{24-27}$

Lipid and protein amounts were $15.49 \pm$ 0.76 and $8.06 \pm 0.26 \mathrm{~g} / 100 \mathrm{~g}$, respectively. A lower protein content of $7.1 \mathrm{~g} / 100 \mathrm{~g}$ was determined ${ }^{24}$, while a level of $8.4 \mathrm{~g} / 100 \mathrm{~g}$ was found for lipids. ${ }^{28}$ Carbohydrates showed quantities of $59.20 \pm 0.58 \mathrm{~g} / 100 \mathrm{~g}$, being the 
highest calorie contributor. A content of $17.96 \pm 0.04 \mathrm{~g} / 100 \mathrm{~g}$ was found for fibers. The ash level was $3.71 \pm 0.15 \mathrm{~g} / 100 \mathrm{~g}$, it agrees with values previously obtained. ${ }^{24,27}$. A total energy of $391 \pm 2.26 \mathrm{kcal} / 100 \mathrm{~g}$ dry basis was observed. The differences in the proximate composition previously reported for aroeira may be due the use of different cultivars in analysis, as well as growing condition.

\subsection{Fatty acids composition}

A total of 10 main fatty acids were identified and quantified in samples (Table 1). Oleic acid (C18:1n9c), palmitic acid (C16:0) and linoleic acid (C18:2n6c) were predominant, with contents as follows: 34.51 $\pm 0.50 \mathrm{~g} / 100 \mathrm{~g}$ (oleic acid), $24.53 \pm 0.38 \mathrm{~g} / 100$ $\mathrm{g}$ (palmitic acid) and $17.58 \pm 0.09 \mathrm{~g} / 100 \mathrm{~g}$ (linoleic acid), respectively.

Same fatty acids were determined as principal in Schinus terebinthifolius Raddi fruit; however, linoleic acid was found to be the most representative one. ${ }^{29}$ Saturated fatty acids such as palmitic, stearic, eicosanoic, heneicosanoic, and docosanoic acids were identified in ethanolic extract of aroeira fruit, with higher contents for stearic and palmitic acids, as it was observed in this study. ${ }^{30}$

The fatty acid percentages decreased in the order of saturated (SFA, $36.77 \mathrm{~g} / 100 \mathrm{~g}$ ) > monounsaturated (MUFA, $36.52 \mathrm{~g} / 100 \mathrm{~g}$ ) > polyunsaturated (PUFA, $19.16 \mathrm{~g} / 100 \mathrm{~g}$ ). Thus, aroeira fruit presented a PUFA/SFA ratio of 0.52 .

Fatty acids are crucial elements on human health. The main fatty acid of aroeira samples, oleic acid, reduces the levels of total cholesterol, triglycerides, low density proteins (LDL), and high density proteins (HDL). ${ }^{31}$ Linoleic acid, the main $n-6$ PUFA identified in this study, presents potential anti-inflammatory, antiadipogenic, antidiabetic, and antihypertensive functions. ${ }^{32}$
Representing the $n-3$ group, eicosapentaenoic (C20:5n3, $0.92 \pm 0.03 \mathrm{~g} / 100$ $\mathrm{g})$ and $\alpha$-linolenic (C18:3n3, $0.13 \pm 0.04 \mathrm{~g} / 100$ g) were found in aroeira. Besides the cardiovascular protective effect of eicosapentaenoic acid, it exerts a relevant impact on arthritis, hypertension, cancer and other inflammatory and autoimmune disorders. ${ }^{14,15} \alpha$-linolenic, occurring primarily in plants, also provides potential cardiovascular benefits when ingested. ${ }^{33}$

\subsection{Phytosterols}

Phytosterols such as $\beta$-sitosterol, stigmasterol, and campesterol were identified and quantified in Schinus terebinthifolius Raddi samples (Table 2). The main phytosterol found was $\beta$-sitosterol, with a level of $166.70 \pm 4.44 \mathrm{mg} / 100 \mathrm{~g}$. The amounts of stigmasterol and campesterol were $26.09 \pm 0.36$ and $3.58 \pm 0.44 \mathrm{mg} / 100 \mathrm{~g}$, respectively. Thus, aroeira samples presented a total phytosterol content of $196.60 \pm 5.00$ $\mathrm{mg} / 100 \mathrm{~g}$.

To our knowledge, no studies were found available in the literature regarding aroeira phytosterols profile for comparison. Wang et al. studied the phytosterol profile and found total contents varying from 150.4 to 1230.9 , 129.6 to $275.6,18.9$ to 255.2 and 11.9 to 93.8 $\mathrm{mg} / 100 \mathrm{~g}$ in vegetable oil, legumes, nuts and cereals, respectively. ${ }^{34}$ Considering theses values, aroeira may be considered a good source of such components.

$\beta$-sitosterol, stigmasterol, and campesterol were also determined in red pepper (Capsicum annuum L.) fruits. In comparison with aroeira, lower quantities of $\beta$-sitosterol were determined (from to 9.85 to $10.7 \mathrm{mg} / 100 \mathrm{~g}$ ), while campesterol presented results in the same range (from 2.49 to 2.70 $\mathrm{mg} / 100 \mathrm{~g}){ }^{35} \mathrm{Kim}$ et al. performed a study to evaluate the phytosterol content of 5 pepper fruit cultivars and observed stigmasterol levels of $10.44,4.52$ and $10.76 \mathrm{mg} / 100 \mathrm{~g}$ for green pepper (Put pepper), red pepper (Hong 
pepper) and violet pepper (Gaji pepper), respectively. ${ }^{36}$

Phytosterols naturally occurring in food from vegetal origin has been demonstrating several benefits to human health. They may influence cholesterol absorption and reduce cholesterol levels in blood. Rich phytosterol diets may also contribute for the reduction of cancers development in $20 \%{ }^{13}$ Thus, due to the difficulty of obtaining phytosterols in diets based on low consumption of foods from vegetal origin, natural sources as aroeira may be applied as active ingredients in many food products and dishes, improving their nutritious value.

\subsection{Determination of total phenolic contents and antioxidant properties}

The results obtained for the total phenolics and the antioxidant capacities determined by DPPH, ABTS and FRAP assays are shown in Table 3 . The total phenolic content was $13.06 \pm 0.09 \mathrm{mg} \mathrm{GAE} / \mathrm{g}$ of dry sample.

Previous studies found higher contents for aroeira fruit, with values of $20.13 \mathrm{mg} \mathrm{GAE} / \mathrm{g}^{28}$ and about $270 \mathrm{mg} \mathrm{GAE} / \mathrm{g} .{ }^{29}$ Other authors demonstrated that experimental conditions applied during extraction direct affect results of total phenolics using the Folin-Ciocalteu reagent. Aroeira extracts obtained by Soxhlet showed an amount of $5.44 \mathrm{mg}$ GAE/g of extract, while the same sample presented a level nearly 20 times higher when the extract was obtained by maceration. ${ }^{37}$ By evaluating different methods (ultrasound-assisted extraction, soxhlet, supercritical fluid extraction) and solvents (ethyl acetate, ethanol, hexane), contents ranging from $2.9 \pm$ 0.4 to $60 \pm 1.0 \mathrm{mg} \mathrm{GAE} / \mathrm{g}$ extract were observed. ${ }^{9}$

Besides the methodology, solvent and experimental condition applied to obtain a natural extract, several factors such as cultivar, origin and geographical growing location, growing conditions, seasonal variations, and storage conditions may influence plants composition, resulting in the great diversity of results available in the literature.

Regarding the antioxidant capacity, Schinus terebinthifolius Raddi extract was evaluated by 3 distinct methods, DPPH, FRAP and ABTS (Table 3). Due to the complexity of natural extracts composition, when a single assay is employed to determine the antioxidant capacity it is not possible to achieve a consistent result that considers the action of all groups of antioxidant compounds present in the matrix. Thus, different methods should be applied to obtain more accurate results, since different methods present different experimental conditions and principles. ${ }^{38}$

The DPPH assay exhibited inhibition of $42.93 \pm 3.40 \%$. In other scientific studies, aroeira ethanolic extracts were analyzed showing inhibition percentage of $35.58^{26}$, $53^{39}$ and $60 \%,{ }^{37}$ while methanolic extracts presented antioxidant activity of $95.6 \%{ }^{8}$ Results in the same range were found for red pepper (Capsicum annuum L.), with DPPH percentages varying from approximately 43 to $48 \% .^{40}$

Aroeira fruit also exhibited antioxidant capacity by ABTS and FRAP assays, presenting values of $348.20 \pm 3.07 \mu \mathrm{mol} \mathrm{TE} / \mathrm{g}$ dry sample and $189.58 \pm 2.39 \mu \mathrm{mol} \mathrm{Fe}{ }^{2+/} \mathrm{g}$ dry sample, respectively. Other authors evaluated aroeira by FRAP and ABTS assays, demonstrating its antioxidant potential by these methods. FRAP was employed to analyze ethanolic extracts of aroeira leaves. ${ }^{41} \mathrm{Da}$ Silva et al. found percentages of inhibition varying from 63.21 to $90.41 \%$ in methanolic extracts of leaves analyzed by the ABTS assay. ${ }^{42}$ Essential oil of aroeira fruit also exhibited antioxidant potential when ABTS assay was applied by Bendaoud et al. $^{43}$

Considering other species, Rufino et al. evaluated 18 Brazilian tropical fruits using FRAP assay and found values hanging from 16.1 to $2502 \mu \mathrm{mol} \mathrm{Fe}^{2+/ g}$ (dry basis). In comparison with the results obtained in our study, puçá-preto (Mouriri pusa), camu-camu (Myrciaria dubia) and acerola (Malpighia 
emarginata) presented higher results, while lower ones were observed for cajá (Spondias mombin), umbu (Spondias tuberosa) and carnaúba (Copernicia prunifera). When evaluated by the ABTS method, the fruits ranged from 16.4 to $1237 \mu \mathrm{mol} \mathrm{TE} / \mathrm{g}$ (dry matter). ${ }^{23}$

Lower values were observed by Kim et al. when applying ABTS assay for Capsicum annuum L.extracts with results varying from 24.34 to $66.42 \mu \mathrm{mol} \mathrm{TE} / \mathrm{g}$ dry sample. ${ }^{44}$ Different genotypes of pepper (Capsicum sp.) also showed lower ABTS values, hanging from 46.79 to $113.08 \mu \mathrm{mol} \mathrm{TE} / \mathrm{g}{ }^{45}$ Jabuticaba (Myrciaria jaboticaba) and jussara (Euterpe edulis) fruits presented lower values when evaluated by FRAP. ${ }^{46}$

\section{Conclusion}

The presence of phytosterols (campesterol, stigmasterol, and $\beta$-sitosterol) and fatty acids in Schinus terebinthifolius Raddi samples offers established beneficial health effects. Overall, aroeira fruit exhibited an antioxidant capacity in DPPH, FRAP and ABTS assays, as well as phenolic compounds content. Thus, the findings of the present study support the valorization and exploitation of Schinus terebinthifolius Raddi fruit, suggesting its use as a natural source of natural antioxidants and other healthpromoting compounds by the food industry, since it may improve the nutritional quality of products and provide good advantages for consumer health.

\section{References}

${ }^{1}$ Chang, S. K.; Alasalvar, C.; Shahidi, F. Superfruits: Phytochemicals, antioxidant efficacies, and health effects-A comprehensive. Critical Reviews in Food Science and Nutrition 2019, 59, 1580. [CrossRef] [PubMed]
${ }^{2}$ Thakur, A.; Sharma, R. Health Promoting Phytochemicals in Vegetables: A Mini Review. International Journal of Food and Fermentation Technology 2018, 8, 107. [CrossRef]

${ }^{3}$ Francelin, M. F.; Vieira, T. F.; Garcia, J. A. A.; Correa, R. C. G.; Monteiro, A. R. G.; Bracht, A.; Peralta, R. M.; Em: Phytochemicals in Vegetables: A Valuable Source of Bioactive Compounds, Bentham Books: Nova lorque, 2018. [CrossRef]

${ }^{4}$ Carvalho, M. G.; Melo, A. G. N.; Aragão, C. F. S.; Raffin, F. N.; Moura, T. F. A. L. Schinus terebinthifolius Raddi: Chemical composition, biological properties and toxicity. Brazilian Journal of Medicinal Plants 2013, 15, 158. [CrossRef]

${ }^{5}$ Lenzi, M.; Orth, A. I. Caracterização funcional do sistema reprodutivo da aroeiravermelha (Schinus terebinthifolius Raddi), em Florianópolis, SC, Brasil. Revista Brasileira de Fruticultura 2004, 26, 198. [CrossRef]

${ }^{6}$ Patocka, J.; de Almeida, J. D. Brazilian pepper tree: Review of pharmacology. Military Medical Science Letter 2017, 86, 32. [CrossRef]

${ }^{7}$ Feuereisen, M. M.; Barraza, M. G.; Zimmermann, B. F.; Schieber, A.; Schulzekaysers, N. Pressurized liquid extraction of anthocyanins and biflavonoids from Schinus terebinthifolius Raddi: A multivariate optimization. Food Chemistry 2017, 214, 564. [CrossRef]

${ }^{8}$ Bernardes, N. R.; Heggdorne-Araújoa, M.;:Borgesb, I. F. J. C.; Almeida, F. M.; Amaral, E. P.; Lasunskaia, E. B.; Muzitano, M. F.; Oliveira, D. B. Nitric oxide production, inhibitory, antioxidant andantimycobacterial activities of the fruits extract and flavonoid content of Schinus terebinthifolius. Revista Brasileira de Farmacognosia 2014, 24, 644. [CrossRef]

${ }^{9}$ Andrade, K. S.; Poncelet, D.; Ferreira, S. R. S. Sustainable extraction and encapsulation of pink pepper oil. Journal of Food Engineering 2017, 204, 38. [CrossRef] 
${ }^{10}$ Shahidi, F.; Ambigaipalan, P. Phenolics and polyphenolics in foods, beverages and spices: Antioxidant activity and health effects - A review. Journal of Functional Food 2015, 18, 820. [CrossRef]

${ }^{11}$ Perez-Vizcaino, F.; Fraga, C. G. Research trends in flavonoids and health. Archives of Biochemistry and Biophysics 2018, 646, 107. [CrossRef] [PubMed]

${ }^{12}$ Seca, A. M.; Pinto, D. C. Biological Potential and Medical Use of Secondary Metabolites. Medicines 2019, 6, 66. [CrossRef]

${ }^{13}$ Shahzad, N.; Khan, W.; Shadab, M. D.; Ali, A.; Saluja, S. S.; Sharma, S.; Al-Allaf, F. A.; Abduljaleel, Z.; Ibrahim, I. A. A.; AbdelWahab, A. F.; Afify, M. A; Al-Ghamdi, S. S. Phytosterols as a natural anticancer agent: Current status and future perspective. Biomedicine \& Pharmacotherapy 2017, 88, 786. [CrossRef] [PudMed]

${ }^{14}$ Calder, P. C. Functional roles of fatty acids and their effects on human health. Journal of Parenteral and Enteral Nutrition 2015, 39, 18S. [CrossRef]

${ }^{15}$ Saini, R. K.; Keum, Y. S. Omega-3 and omega- 6 polyunsaturated fatty acids: Dietary sources, metabolism, and significance-A review. Life Sciences 2018, 203, 255. [CrossRef]

${ }^{16}$ AOAC; Official Methods of Analysis, 16th ed., Association of Official Analytical Chemists: Arlington, 1995.

${ }^{17}$ INSTITUTO ADOLFO LUTZ. Normas Analíticas do Instituto Adolfo Lutz. Métodos químicos e físicos para análise de alimentos, São Paulo, 2008.

${ }^{18}$ Huang, Z. L.; Wang, B. W.; Crenshaw, A. A. A simple method for analysis of trans fatty acid with GC-MS and ATTM- Silar-90 capillary column. Food Chemistry 2006, 98, 593. [CrossRef]

${ }^{19}$ Saldanha, T.; Sawaya, A. C. F.; Eberlin, M. N.; Bragagnolo, N. HPLC separation and determination of 12 cholesterol oxidation products in fish: comparative study of RI, UV, and APCI-MS detectors. Journal of
Agricultural and Food Chemistry 2006, 54, 4107. [CrossRef]

${ }^{20}$ Menéndez-Carreño, M.; García-Herreros, C.; Astiasarán, I., Ansorena, D. Validation of a gas chromatography-mass spectrometry method for the analysis of sterol oxidation products in serum. Journal of Chromatography B 2008, 864, 61. [CrossRef] [PubMed]

${ }^{21}$ Torres, D. E. G.; Assunção, D.; Mancini, P.; Torres, R. P.; Mancini-Filho, J. Antioxidant activity of macambo (Theobroma bicolor L.) extracts. European Journal Lipid Science Technology 2002, 104, 278. [CrossRef]

${ }^{22}$ Quettier-Deleu, C.; Gressier, B.; Vasseur, J.; Dine, T.; Brunet, C.; Luyckx, M.; Cazin, M.; Cazin, J.-C.; Bailleul, F.; Trotin, F. Phenolic compounds and antioxidant activities of buckwheat (Fagopyrum esculentum Moench) hulls and flour. Journal Ethnopharmacology, 2000, 72, 35. [CrossRef] [PubMed]

${ }^{23}$ Rufino, M. D. S. M.; Alves, R. E.; de Brito, E. S.; Pérez-Jiménez, J.; Saura-Calixto, F.; Mancini-filho, J. Bioactive compounds and antioxidant capacities of 18 non-traditional tropical fruits from Brazil. Food Chemistry 2010, 121, 996. [CrossRef]

${ }^{24}$ Gonçalves, F. G.; Zanini, S. F.; Feitosa, M. L.; Gonçalves, E. P. M.; Colnago, G. L. Efeito da pimenta rosa quando associado a diversas doses de antibióticos em frangos de corte. Ciência Rural 2012, 42, 1503. [CrossRef]

${ }^{25}$ Souza, A. R. M.; Arthur, V.; Nogueira, D. P. The effects of irradiation in the preservation of pink pepper (Schinus terenbinthifolius Raddi). Radiation Physics and Chemistry 2012, 81, 1082. [CrossRef]

${ }^{26}$ Labre, T. S.; Rodrigues, N.; Augusta, I. M.; Barbosa Junior, J. L.; Saldanha, T. Composição centesimal e caracterização da atividade antioxidante de frutos e da farinha de Schinus terebinthifolius Raddi (Anacardiacea). Magistra 2013, 25, 1.

${ }^{27}$ Pagani, A. A. C.; Souza, A. L. G.; Souza, D. S.; Batista, R.; Xavier, A. C. R.; Pagani, G. D. Quantification of Bioactive Compounds of Pink Pepper (Schinus Terebinthifolius, Raddi). 
International Journal of Engineering and Innovative Technology 2014, 4, 37. [Link]

${ }^{28}$ Santana, A. G.; Araújo, J. S. F.; Gonçalves, M. C.; Resumo do I Congresso Internacional de Diversidades do Semiárido, Natal, Brasil, 2018.

${ }^{29}$ Ennigrou, A.; Casabianca, H.; Laarif, A.; Hanchi, B.; Hosni, K. Maturation-related changes in phytochemicals and biological activities of the Brazilian pepper tree (Schinus terebinthifolius Raddi) fruits. South African Journal of Botany 2017, 108, 407. [CrossRef]

${ }^{30}$ da Silva, J. H.; Simas, N. K.; Alviano, C. S.; Alviano, D. S.; Ventura, J. A.; de Lima, E. J., Seabra, S.; Kuster, R. M. Anti-Escherichia coli activity of extract from Schinus terebinthifolius fruits and leaves. Natural Product Research 2018, 32, 1365. [CrossRef] [PubMed]

${ }^{31}$ Sales-Campos, H.; de Souza, P. R.; Peghini, B. C.; da Silva, J. S.; Cardoso, C. R. An overview of the modulatory effects of oleic acid in health and disease. Mini Reviews in Medicinal Chemistry 2013, 13, 201. [CrossRef] [PubMed]

32 Viladomiu, M.; Hontecillas, R.; BassaganyaRiera, J. Modulation of inflammation and immunity by dietary conjugated linoleic acid. European Journal of Pharmacology 2016, 785, 87. [CrossRef] [PubMed]

${ }^{33}$ Ganguly, R.; Hasanally, D.; Stamenkovic, A.; Maddaford, T. G.; Chaudhary, R.; Pierce, G. N.; Ravandi, A. Alpha linolenic acid decreases apoptosis and oxidized phospholipids in cardiomyocytes during ischemia/reperfusion. Molecular and Cellular Biochemistry 2018, 437, 163. [CrossRef] [PubMed]

${ }^{34}$ Wang, M.; Huang, W.; Hu, Y.; Zhang, L.; Shao, Y.; Wang, M.; Zhang, F.; Zhao, Z.; Mei, X.; Li, T.; Wang, D.; Liang, Y.; Li, J.; Huang, Y.; Zhang, L.; Xu, T.; Song, H.; Zhong, Y.; Lu, B. Phytosterol profiles of common foods and estimated natural intake of different structures and forms in China. Journal of Agricultural and Food Chemistry 2018, 66, 2669. [CrossRef]
${ }^{35}$ Bhandari, S. R.; Bashyal, U.; Lee, Y. S. Variations in proximate nutrients, phytochemicals, and antioxidant activity of field-cultivated red pepper fruits at different harvest times. Horticulture, Environment, and Biotechnology 2016, 57, 493. [CrossRef]

${ }^{36}$ Kim, T. J.; Choi, J.; Kim, K. W.; Ahn, S. K.; Ha, S. H.; Choi, Y.; Park, N. I.; Kim, J. K. Metabolite profiling of peppers of various colors reveals relationships between tocopherol, carotenoid, and phytosterol content. Journal of Food Science 2017, 82, 2885. [CrossRef]

${ }^{37}$ D'Sousa'Costa, C. O.; Ribeiro, P. R.; Loureiro, M. B.; Simões, R. C.; de Castro, R. D.; Fernandez, L. G. Phytochemical screening, antioxidant and antibacterial activities of extracts prepared from different tissues of Schinus terebinthifolius Raddi that occurs in the coast of Bahia, Brazil. Pharmacognosy Magazine, 2015, 11, 607. [CrossRef]

${ }^{38}$ Barros, R. G. C.; Andrade, J. K. S.; Denadai, M.; Nunes, M. L.; Narain, N. Evaluation of bioactive compounds potential and antioxidant activity in some Brazilian exotic fruit residues. Food Research International 2017, 102, 84. [CrossRef] [PubMed]

${ }^{39}$ Degáspari, C. H.; Waszczynskyj, N.; Prado, M. R. M. Antimicrobial activity of Schinus terebenthifolius Raddi. Ciência $e$ Agrotecnologia 2005 29, 617. [CrossRef]

${ }^{40}$ Deng, L. Z.; Yang, X. H.; Mujumdar, A. S.; Zhao, J. H.; Wang, D.; Zhang, Q.; Wang, J.; Gao, Z.; Xiao, H. W. Red pepper (Capsicum annuum L.) drying: effects of different drying methods on drying kinetics, physicochemical properties, antioxidant capacity, and microstructure. Drying Technology 2018, 36, 893. [CrossRef]

${ }^{41}$ Woraratphoka, J.; Intarapichet, K. O.; Indrapichate, K. Antioxidant activity and cytotoxicity of six selected, regional, Thai vegetables. American-Eurasian Journal of Toxicological Science 2012, 4, 108. [Link]

${ }^{42}$ da Silva, M. M.; Iriguchi, E. K.; Kassuya, C. A. L.; do Carmo Vieira; M., Foglio, M. A.; de Carvalho, J. E.; Ruiz, A. L. T. G.; Souza, K. P.; 
Formagio, A. S. Schinus terebinthifolius: phenolic constituents and in vitro antioxidant, antiproliferative and in vivo antiinflammatory activities. Revista Brasileira de Farmacognosia 2017, 27, 445. [CrossRef]

${ }^{43}$ Bendaoud, H.; Romdhane, M.; Souchard, J. P.; Cazaux, S.; Bouajila, J. Chemical composition and anticancer and antioxidant activities of Schinus molle L. and Schinus terebinthifolius Raddi berries essential oils. Journal of Food Science 2010, 75, C466. [CrossRef]

${ }^{44}$ Kim, H. G.; Bae, J. H.; Jastrzebski, Z.; Cherkas, A.; Heo, B. G.; Gorinstein, S.; Ku, Y. G. Binding, antioxidant and anti-proliferative properties of bioactive compounds of sweet paprika (Capsicum annuum L.). Plant Foods for Human Nutrition 2016, 71, 129. [CrossRef]
${ }^{45}$ Carvalho, A. V.; de Andrade Mattietto, R.; de Oliveira Rios, A.; de Almeida Maciel, R.; Moresco, K. S.; de Souza Oliveira, T. C. Bioactive compounds and antioxidant activity of pepper (Capsicum sp.) genotypes. Journal of Food Science and Technology 2015, 52, 7457. [CrossRef]

${ }^{46}$ Inada, K. O. P.; Oliveira, A. A.; Revorêdo, T. B.; Martins, A. B. N.; Lacerda, E. C. Q.; Freire, A. S.; Braz, B. F.; Santelli, R. E.; Torres, A. G.; Perrone, D.; Monteiro, M. C. Screening of the chemical composition and occurring antioxidants in jabuticaba (Myrciaria jaboticaba) and jussara (Euterpe edulis) fruits and their fractions. Journal of Functional Foods 2015, 17, 422. [CrossRef] 